\title{
Enzymatic Hydrolysis of Fish Frames Using Pilot Plant Scale Systems
}

\author{
Aristotelis T. Himonides ${ }^{1^{*}}$, Anthony K. D. Taylor ${ }^{2}$, Anne J. Morris ${ }^{2}$ \\ ${ }^{1}$ Technological Educational Institute, Thessaloniki, Greece; ${ }^{2}$ University of Lincoln, Minerva House, Holbeach, United Kingdom. \\ Email: *thimoni@teithe.gr \\ Received May $16^{\text {th }}, 2011$; revised June $30^{\text {th }}, 2011$; accepted July $7^{\text {th }}, 2011$.
}

\begin{abstract}
Papain was used to hydrolyse fish frames under controlled conditions at a batch-pilot plant scale-process, for the production of fish protein hydrolysates (FPH). Mass balance calculations were carried out so that the rate of hydrolysis, rate of protein solubilisation and yields could be estimated. Almost complete hydrolysis could be achieved in 1 hour, at $40{ }^{\circ} \mathrm{C}$, with no $\mathrm{pH}$ adjustment, at $0.5 \%\left(5 \mathrm{~g} \cdot \mathrm{kg}^{-1}\right)$ enzyme to substrate ratio $(\mathrm{E} / \mathrm{S}$, were $S$ is Kjeldahl protein) using whole fish frames (including heads and flaps). This was achieved both with the addition of water (1/1 to 2/1 frames/water) but more importantly from commercial considerations without the initial addition of water (after mincing of the fish material). The degree of protein solubilisation ranged between $71 \%-86 \% \mathrm{w} / \mathrm{w}$. Four different processes are described, namely: 1) a soluble spray-dried FPH powder; 2) a liquid FPH; 3) a partly soluble, spray dried FPH powder and;4) a crude, drum-dried protein for animal consumption. The amino acid profile of the FPH was identical to that of the parent substrate (fish frames).
\end{abstract}

Keywords: Enzymatic Hydrolysis, Papain, Cod, Haddock, Frames, Molecular Weight Distribution, Degree of Hydrolysis

\section{Introduction}

The enzymatic hydrolysis of a complicated and non- pure food protein such as the fish flesh/frame, cannot be accurately described or predicted solely by the application of existing kinetic models and laws. The natural existence of enzyme inhibitors and the variability in the susceptibility of different bonds to different enzymes are only two of the main complicating factors [1]. Such enzymatic hydrolysis should be regarded as a combination of parallel and consecutive occurring reactions [1]. Because of this complexity, it is extremely difficult (and also not the intention here) to describe the mechanism of hydrolysis and/or enzyme kinetics in any detail.

A general outline of the mechanism of the enzymatic hydrolysis of a fish protein substrate is described by a number of authors $[2,3]$.

The current investigation of the enzymatic hydrolysis of fish flesh is aimed primarily at the industrial application of the process. This poses constraints, particularly with respect to the overall cost efficiency of the scaledup process. Low cost and simplicity in operation, by reducing the cost of material, energy consumption and labour, but maintaining high productivity are some of the important attributes that outline the direction of this investigation.

Preceding work [4] involving a laboratory scale hydrolysis model, investigated the behaviour of the most appropriate enzymes on a well defined substrate, with particular interest in the overall rate of hydrolysis and the molecular weight distribution of the final hydrolysate at different degrees of hydrolysis. This work provided information for the selection of the most suitable hydrolysis parameters (i.e. substrate concentration, substrate/enzyme concentration ratio, $\mathrm{pH}$ and temperature) used during the pilot plant experiments.

\section{Experimental}

Cod and haddock fish frames (remains of the fish after the removal of the guts and the fillets) were supplied daily (J. W. Moores Ltd., Grimsby). Both headless and heads-on frames were used. These were hydrolysed either whole, or after mincing (using a bowl-chopper).

Hydrolysis was carried out with papain from papaya latex (EC 3.4.22.2, p.n. P-3250 supplied by Sigma).

Hydrolyses were performed using a $50 \mathrm{~L}$ steel jacketed vessel heated by steam. The unit was equipped with a 
temperature regulator. An electric motor with a propeller-like paddle was used to stir the contents of the vessel.

Whole frames were hydrolysed with different volumes of water, ranging from $1 / 1$ to $1 / 2$ water to frames ratio $(\mathrm{w} / \mathrm{w})$. Minced frames were hydrolysed without the addition of water.

The material was hydrolysed at approximately $20 \mathrm{~kg}$ batches of fish waste.

The enzyme to substrate concentration $(\mathrm{E} / \mathrm{S}$, were $\mathrm{S}=$ Kjeldahl protein) ranged from $3-10 \mathrm{~g} \cdot \mathrm{kg}^{-1}(\mathrm{w} / \mathrm{w})$. The enzyme preparation was blended with $100 \mathrm{ml}$ of distilled water before addition to the hydrolysis mixture. Hydrolysis was carried out at $40^{\circ} \mathrm{C}$ for 1 hour and then at higher temperatures $\left(\sim 78^{\circ} \mathrm{C}\right)$ so as to combine the hydrolysis stage with the pasteurisation stage. The $\mathrm{pH}$ of the hydrolysis mixture was not adjusted. The enzyme was selected at the first place to show excellent overall activity at near neutral $\mathrm{pH}$. This was also proven during the model systems.

The progress of hydrolysis was recorded in a number of experiments by the application of the $\mathrm{pH}$-stat [4]. The duration of hydrolysis was such as to ensure that hydrolysis entered into the stationary phase (approximately 1 hour).

\subsection{Mass-Balance Calculations}

The following measurements were made prior to and also after hydrolysis.

Mass of frames, water and enzyme.

Mass of total mixture at the end of hydrolysis and/or after pasteurisation.

Mass of decanted liquid (containing soluble and insoluble matter in suspension) after removal of bones.

Protein content (Kjeldahl) for the decanted liquid.

After centrifugation of $1 \mathrm{~kg}$ of a representative sample from the decanted liquid, the following were calculated for the whole batch:

Mass of the supernatant (clear liquid containing soluble proteins).

Protein content of supernatant.

Total solids of the supernatant (drying at $103^{\circ} \mathrm{C}$ until constant weight).

Protein content of sludge.

Moisture of sludge.

\section{Centrifugation}

For larger volumes of liquid and for the production of soluble liquid FPH samples, a laboratory scale "AlfaLaval" centrifuge/clarifier was used. The centrifuge operated at $(5-6) \times 10^{3} \mathrm{rpm}$ and was fitted with a clarifying bowl and cones.

\subsection{Centrifuging Index for Protein (CIP)}

The centrifuging index for protein expresses the degree of protein solubilisation achieved after termination of hydrolysis and was determined without any $\mathrm{pH}$ adjustment.

The hydrolysed fish flesh was centrifuged at $1700 \times \mathrm{g}$ (3000 rpm) for $30 \mathrm{~min}$, using a bench top centrifuge. The supernatants were collected into a beaker.

$1 \mathrm{ml}$ aliquots were removed from the whole mixture prior to and also after centrifugation (from the supernatant) and were analysed for protein content by the Kjeldahl method. The centrifuging index for protein (CIP) was given at a defined $\mathrm{pH}(6.6-6.4)$ and the specific conditions of centrifugation [1].

\subsection{Rotary Vacuum Filtration}

A rotary vacuum filtration unit was also used for the clarification of the "whole" liquid after hydrolysis (containing soluble and insoluble matter).

Prior to filtration of the FPH liquid the unit was operated with an aqueous suspension (slurry) of diatomaceous earth to form a cake on the surface of the filtering support cloth.

The initial temperature of the FPH liquid prior to clarification was approximately $78^{\circ} \mathrm{C}$ and the unit's bath was filled with approximately $5 \mathrm{~L}$ of liquid which was topped up with FPH liquid throughout the operation. The operation was not temperature regulated and thus the temperature progressively decreased.

The speed of rotation was adjusted so that the build-up of insoluble matter appeared to be dry by the time it reached the scraper blade.

\subsection{Drying, Using a Pilot-Plant Scale Spray-Drier}

Two products were fed through the spray-drier, namely the un-clarified (whole) hydrolysis mixture (remaining liquid after removal of bones containing soluble and insoluble matter in suspension) and the clarified liquid containing only soluble protein.

The "whole" liquid was filtered through a wire sieve $(200 \mu \mathrm{m})$ in order to remove any particles that may clog the narrow channels of the atomiser.

The temperature of the feed ranged from $60^{\circ} \mathrm{C}$ to $40^{\circ} \mathrm{C}$ depending on the time allowed to pass between completion of pasteurisation and final processing (spray-drying).

Spray-drying was carried out under the following general settings:

Temperature of drying air: $200^{\circ} \mathrm{C}-300^{\circ} \mathrm{C}$ (depending on load)

Temperature of "wet" air: $110^{\circ} \mathrm{C}-120^{\circ} \mathrm{C}$

Feed rate: $10-20 \mathrm{~kg} \cdot \mathrm{h}^{-1}$

Air pressure at the nozzle: 5 - 7 bars

The dry product was finally stored under vacuum into polyethylene bags. 


\subsection{Determination of FPH Molecular Weight Distribution}

Two Sephadex gel beds were used, a G-15 fine and a G-50 fine (Pharmacia Biotech) with fractionation ranges able to separate proteins/peptides within the range of 0 1500 Daltons and 1500 - 30000 Daltons respectively.

The eluent was phosphate buffer $\left(0.0325 \mathrm{M} \mathrm{K}_{2} \mathrm{HPO}_{4} /\right.$ $\left.0.0026 \mathrm{M} \mathrm{KH}_{2} \mathrm{PO}_{4} / 0.40 \mathrm{NaCl}\right)$ of $\mathrm{pH} 7.6$ and ionic strength 0.5 [1] and had a flow rate of $30 \mathrm{ml} \cdot \mathrm{h}^{-1}$.

The two columns had an internal diameter of $26 \mathrm{~mm}$ (G-50) and $16 \mathrm{~mm}$ (G-15). The length of both gel beds was approximately $54 \mathrm{~cm}$. The column was in series with a flow-through UV spectrophotometer. Absorbance was measured at $206 \mathrm{~nm}$. FPH powder containing $10 \mathrm{mg}$ of Kjeldahl protein $(\mathrm{N} \times 6.25)$ had $1 \mathrm{~g}$ of $\mathrm{NaCl}$ added and then was dissolved into $10 \mathrm{ml}$ of eluent. The mixture was filtered through a fast Watman paper and collected with a disposable syringe.

A sample of $0.5 \mathrm{ml}$ was injected into the columns (sephadex G-15 and G-50).

Standards of known molecular weight were chromatographed in order to construct a calibration curve, used to identify the molecular weight distribution of the proteinhydrolysates.

\subsection{Amino-Acid Analysis Using HPLC}

Protein hydrolysis was achieved using sealed screw-cup acid hydrolysis with $6 \mathrm{~N} \mathrm{HCl}$ (after purging with nitrogen).

The pre-column derivitisation was with dabsyl-Cl and detection at $436 \mathrm{~nm} \mathrm{[5].}$

In trying to demonstrate the sensitivity of the technique Stocchi et al. [5] and also Knecht and Chang [6] described sample preparation procedures that would result in sample concentrations at the low picomole level. In this current analysis adaptations to these procedures were primarily in place, in order to achieve higher sample concentrations (and thus except to work with greater accuracy) and also avoid problems related to reagent contamination [6]. In order to ensure a linear relation between amino-acid quantity subjected to dabsylation and molar absorbance of the derivative, it was important that the molar concentration of Dabsyl-Cl was at least 4-fold greater than that of the total amino-acids and that the $\mathrm{pH}$ of reaction was 9.0 [7]. Higher sample concentrations may also entail problems with sample solubility thus requiring higher volumes and/or stronger buffers to achieve accurate $\mathrm{pH}$ control. A mixture of the essential amino-acids (plus taurine) used as standards for the characterisation of the fish protein hydrolysates, was successfully separated using the method proposed by Stoc- chi et al. [5]. The identification of the unknown peaks (standard mixture) was carried out by means of injecting individual amino-acid standards and identifying the peaks with similar retention times and matching spectra (200 - $500 \mathrm{~nm}$ ).Calibration curves were prepared for each amino-acid, by injecting four dilutions of the standard amino-acid mixture.

\section{Results and Discussion}

\subsection{Hydrolysis of Headless Frames}

During initial hydrolysis experiments, carried out at $40^{\circ} \mathrm{C}$, using headless cod frames with $6 \mathrm{~g}$ enzyme per kg protein and $1 / 1$ frames to water ratios, more than $84 \%$ of the total protein content was solubilised in less than $60 \mathrm{~min}$. Centrifuging protein index (CIP) calculations (for the measurement of protein solubilisation) showed protein solubilisation to have entered into a stationary phase at that point. This is comparable to what was observed during the model system hydrolyses (using fillets) carried out under similar conditions. Evidently the use of fish frames (rather than fillets) as substrate for hydrolysis does not appear to significantly hinder the rate of hydrolysis. Mohr [2] concurs that the highly organised arrangement of the proteins (sarcoplasmic, myofibrillar, stroma) in the tissue is appeared not to cause the proteins to be less accessible for proteolytic attack. Kristinsson and Rasco [3] explained the hydrolytic attack of fish myosin by enzymes such as trypsin, chymotrypsin and papain.

Possible increase to the rate of hydrolysis through the increase of enzyme concentration was not further investigated. Bhumiratana et al. [8] states that since the amount of enzyme adsorbed onto the surface of the solid particles depends on the adsorption isotherm, the rate of hydrolysis is not necessarily increased directly by the increase of the enzyme concentration. Having established a successful hydrolysis at $1 / 1$ frames to water ratio, the following adaptations were made to try to increase the economy and industrial feasibility 1) the use of heads-on frames; 2) the concentration of the substrate; and 3) the increase of the hydrolysis temperature.

\subsection{Hydrolysis of Whole, Heads-on Frames}

Hydrolysis of heads-on frames was successful and as rapid as the hydrolysis of the rest of the fish frame and did not significantly alter the protein composition of the final mixture. After centrifugation of the hydrolysed mixture consisting of heads, a small amount of insoluble particles floating on the surface of the supernatant were observed. This was not investigated further but was thought to be fat, or cholesterol from the fish brains. 


\subsection{Increase of Hydrolysis Temperature}

The increase of hydrolysis temperature aimed to complete hydrolysis at a temperature/time combination which was also sufficient to pasteurise the mixture. Pasteurisation was complete when the mixture was held at $78^{\circ} \mathrm{C}$ for at least $25 \mathrm{~min}$. These conditions far exceed the requirements for the pasteurisation of milk [9]. Within the time required for the hydrolysis mixture to reach and maintain that temperature (i.e. $25 \mathrm{~min}$ ) complete hydrolysis had also occurred. A single stage process, avoiding the use of a pasteurizer might be preferable for an industrial application.

The temperature of hydrolysis is one of the most important hydrolysis parameters, affecting enzyme activity to a great extent. It can be easily varied to match current needs between the duration of hydrolysis at the desired degree of hydrolysis.

\subsection{Concentration of Hydrolysis Mixture}

With the $2 / 1$ whole frames to water ratio there was some difficulty in enzyme distribution, mixing and heat transfer. However, hydrolysis was possible, with a degree of protein solubilisation ranging at approximately $75 \%$ (Table 1).

With the undiluted experiments using whole fish frames, there were practical problems associated with enzyme distribution and mixing at the beginning of hydrolysis. As a result mincing of the material was necessary. The degree of protein solubilisation achieved was $71 \%$ (Table 1). Šližytè et al. [10-12] reported that water to substrate ratio played key role to recovered protein yields from cod by-products and also affected oil separation and emulsion formation. As the cost of the raw material is insignificant, cost effectiveness of the process is increased with an increase in the concentration of fish waste in the hydrolysis mixture by reducing the cost of product dehydration (or concentration) which is by far the most expensive stage of production. This outweighs the reduction in the degree of protein solubilisation and recoveries of soluble proteins. With regards to the kinetics of such hydrolyses, it was shown that the bulk of the

Table 1. Protein solubilisation for the pilot-plant hydrolyses, with and without the addition of water.

\begin{tabular}{cccc}
\hline & \multicolumn{3}{c}{ Frames/water } \\
\hline & $1 / 0$ & $2 / 1$ & $1 / 1$ \\
\hline $\begin{array}{c}\text { Protein concentration of frames } \\
\left(\mathbf{g} \cdot \mathbf{k g}^{-1}\right)\end{array}$ \\
$\begin{array}{c}\text { Soluble protein/total protein } \\
(\%)\end{array}$ & $132 \pm 14$ & $133 \pm 16$ & $118 \pm 9$ \\
\hline
\end{tabular}

(Average values of four experiments, two of which were carried out with heads-on frames with flaps). soluble material is released during the initial stage of hydrolysis. Subsequently the rate of hydrolysis decreases and eventually enters a stationary phase, during which no apparent hydrolysis takes place [2,3]. Product inhibition has been proven by many workers in the hydrolysis of fish and it seems that it accounts for much of the reduction in extent and rate of solubilisation $[2,8,13]$.

Enzyme auto digestion and a low $(\mathrm{Km})$ value for the soluble peptides that act as effective substrate competitors for the unhydrolysed fishprotein are also well documented factors, affecting the shape of hydrolysis [3].

The reduced protein solubilisation observed during the undiluted experiments, could also be ascribed (at least partly) to inaccurate CIP estimation. This could be due to increased solute concentration, causing chemical interactions between soluble peptides with the sludge (insoluble peptides) as well as insolubilisation due to approximation to near saturation point. It is thought that these problems could be addressed by the application of membrane technology (ultra/nano filtration) for the removal of hydrolysed peptides (below a given size) thus avoiding further hydrolysis and controlling product inhibition.

\subsection{Alternative Processing Paths}

The suggested industrial FPH production was designed to be versatile rather than single ended. Four different products could be produced, i.e. a soluble protein powder, a partly soluble powder from the "whole" unseparated hydrolysis mixture, a drum dried sludge and finally a clear liquid, the selection of which will most likely depend on the available equipment, market demands and other financial parameters.

The entire production of FPH (including the alternative processing paths) is outlined in Figure 1. Mass balance calculations for the highest grade FPH powder $(100 \%$ soluble spray dried powder) are shown in Figure 2. Higher yields of a lower grade FPH can be attained by spray-drying the unclarified (whole) hydrolysis liquid.

\subsection{Proximate Composition}

Table 2 shows a representative proximate composition of

Table 2. Proximate composition of pilot-plant scale fish protein hydrolysate samples $\left(\mathrm{g} \cdot \mathrm{kg}^{-1}\right)$.

\begin{tabular}{ccccc}
\hline & $\begin{array}{c}\text { Soluble } \\
\text { powder }\end{array}$ & $\begin{array}{c}\text { Whole } \\
\text { powder }\end{array}$ & $\begin{array}{c}\text { Drum dried } \\
\text { sludge }\end{array}$ & $\begin{array}{c}\text { Clear } \\
\text { liquid }\end{array}$ \\
\hline Protein & 920 & 890 & 900 & 120 \\
Moisture & 50 & 60 & 30 & 860 \\
Ash & 10 & 20 & 30 & 10 \\
Lipids & 10 & 10 & 10 & 10 \\
\hline
\end{tabular}

(Values are averages of duplicate determinations of single samples). 


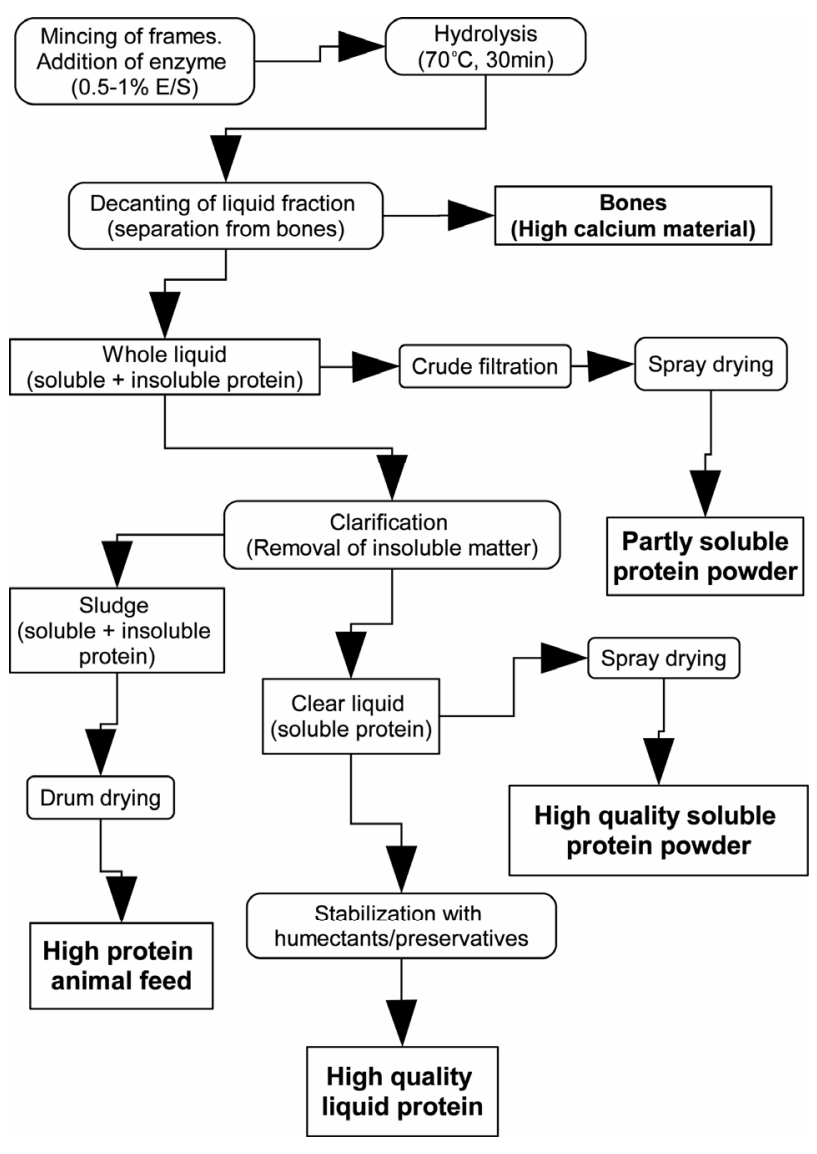

Figure 1. Commercial production of a range of fish protein hydrolysate products.

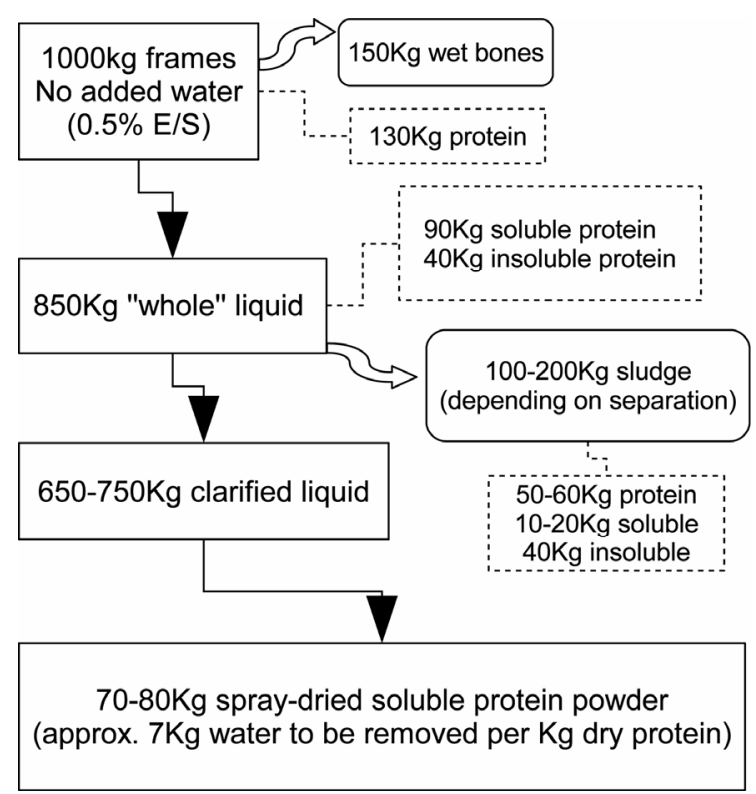

Figure 2. Mass-balance calculations for the production of the soluble fish protein hydrolysate with no added water in the hydrolysis mixture. the FPH samples produced during the pilot-plant scale experiments, using haddock frames.

Where: soluble powder: from the spray-drying of the clarified hydrolysis mixture.

"Whole" powder: from the spray-drying of the sieved hydrolysis mixture.

Drum-dried sludge: from the centrifugation of the hydrolysis mixture.

Clear liquid: after centrifugation (clarification) of the hydrolysis mixture.

\subsection{Molecular Weight Distribution by Gel-Filtration}

FPH powders deriving from either cod, or haddock (with/without heads) all produced similar chromatograms with reproducible elution of the distinctive peaks and the shape of the peaks (Figures 3 and 4 ).

Endopeptidases such as papain are more than adequate for recovering high yields of FPH [14] (unless a more severe hydrolysis is required in which case a mixture of endo/exo-peptidases is preferred). Highly specific endopeptidases result in less severe hydrolysis, producing large molecular weight peptides, compared to low specific proteases [2].

Ideally, hydrolyses must be controlled in such a way that maximum soluble protein, of specific molecular weights could be obtained. For example, if protein functionality is the objective (emulsification, foam formation, etc.) a hydrolysate rich in large peptide molecules is required $[15,16]$. In this case the parameters affecting the degree of hydrolysis must be controlled to allow maximum solubilisation with minimum peptide size reduction. Alternatively, fractionation through membranes (ultra/ nano filtration) was shown [17-22] to provide some control over protein functionality (emulsification, aeration, bio-activities such as anti-oxidation). This is achieved through the production of fractions enriched with peptides of specific molar mass, shown to exhibit such functionalities.

When solubility is the main property required, then a hydrolysate rich in small peptides and free amino-acids is preferable. However the formation of certain oligo-peptides, could produce bitter flavour which is mainly accounted for tri-peptides with hydrophobic N-terminal amino-acids [23-27].

\subsection{Amino-Acid Analysis Using HPLC}

The chromatograms deriving from the "soluble" FPH samples were compared to these of the "whole" FPH and were found to be almost identical.

Fish flesh proteins are of high biological value $[3,28]$. The actual protein composition of the raw material used for hydrolysis (fish frames) is slightly different to that of 


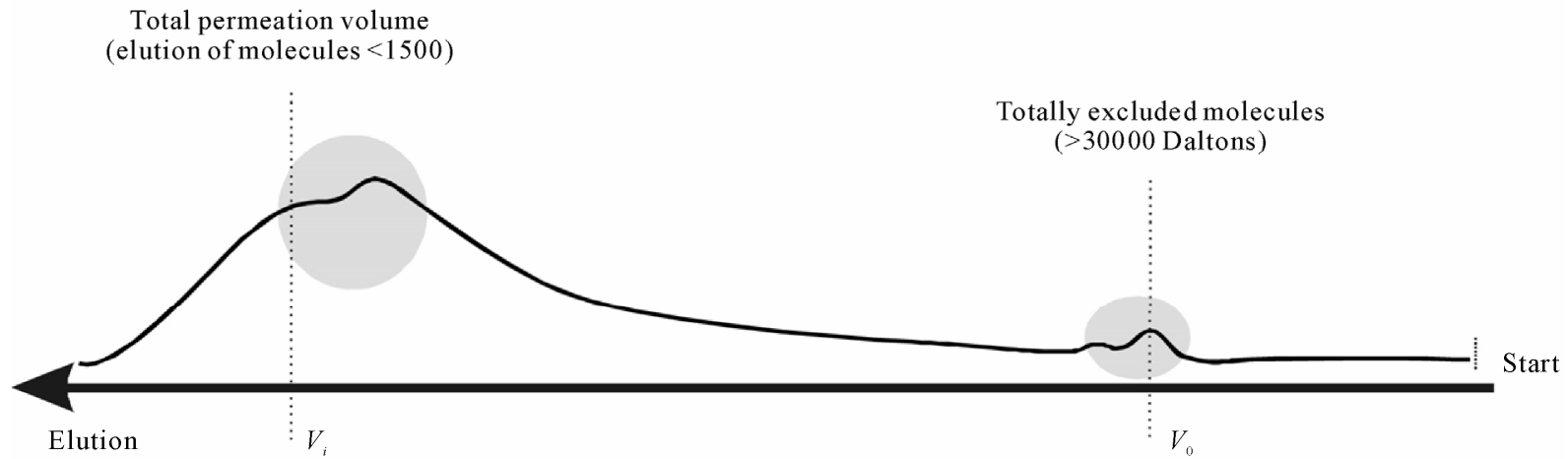

Figure 3. Elution of pilot plant scale fish protein hydrolysate powder after hydrolysis with papain through a Sephadex G-50 $(\mathrm{ABS} 206 \mathrm{~nm})$.

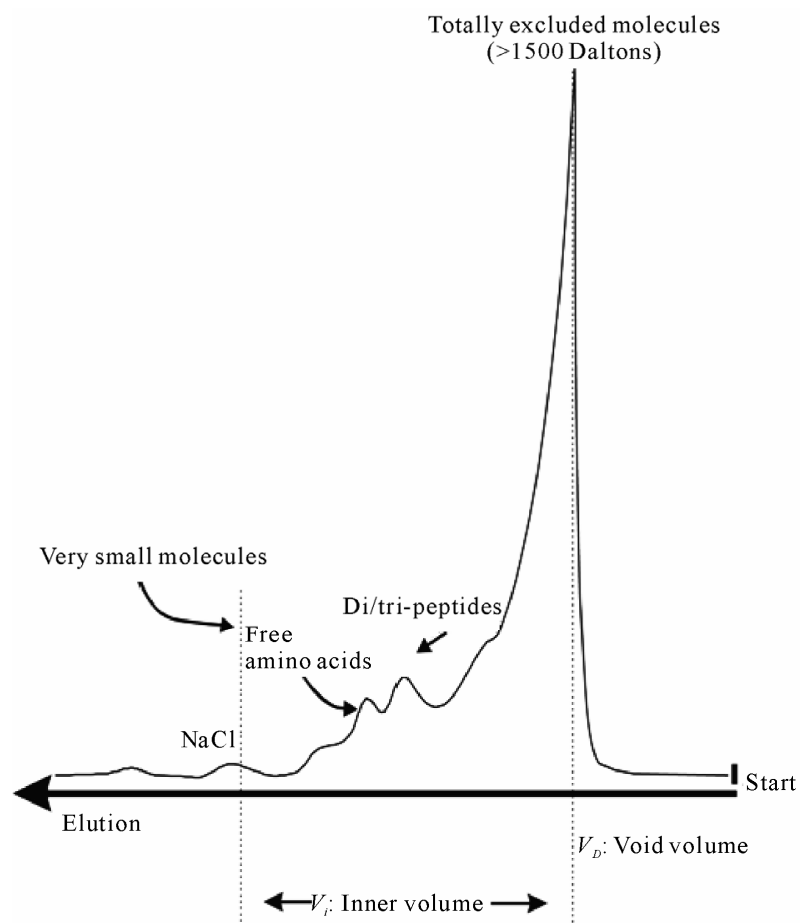

Figure 4. Elution of pilot plant scale fish protein hydrolysate powder after hydrolysis with papain through a Sephadex G-15 (ABS 206 nm).

the fish fillet due to higher blood content, the existence of the gut membrane and the connective tissue from the skeleton. However these proteins (with the exception of cartilage) are of equally high nutritional value. The similarity between the amino-acid profiles of the "soluble" fraction and the "whole" FPH is a good indication of the preservation of the biological value of the FPH. Due to the "mild" conditions during hydrolysis, involving proteolytic enzymes (instead of acid, or alkali) and absence of high temperatures, it was thought that the amino-acid profile of the "whole" FPH should be very similar to the amino-acid profile of the parent protein (fish flesh). This view is also supported by Kristinsson and Rasco [3]. Liaset and Espe [29] found evidence of some segregation between micro and macro nutrients in the soluble and insoluble fractions of FPH from cod, salmon and saithe. More noticeably, they found low levels of tryptophan in all soluble FPH. This correlates well with Sahidi et al. [30] who reported similar amino acid profiles of capelin hydrolysates to that of the parent substrate except for a small reduction in methionine and tryptophan, but this was in the soluble fraction.

\section{Conclusions}

A simple and versatile commercial process for the production of fish protein hydrolysates has been described.

Papain was found suitable for a commercial application of the production of fish protein hydrolysates.

Almost complete hydrolysis could be achieved in 1 hour $\left(40^{\circ} \mathrm{C}\right.$, no $\mathrm{pH}$ adjustment, $\left.0.5 \% \mathrm{E} / \mathrm{S}\right)$ using whole fish frames (including heads and flaps) by the addition of water (1/1-2/1frames/water) or without the initial addition of water, by mincing of the fish material.

The degree of protein solubilisation ranged between $71 \%-86 \% \mathrm{w} / \mathrm{w}$.

Four different products could be produced a) a soluble spray-dried FPH powder; b) a liquid FPH; c) a partly soluble, spray dried FPH powder (these products could be used for human consumption) and; d) a crude, drumdried protein for animal consumption.

\section{Acknowledgements}

The authors greatly acknowledge funding of this research as a European Community RECRAFT project. The Authors also thank Five Star fish Ltd and William Hobson Ltd for collaboration and supply of materials.

\section{REFERENCES}

[1] J. Adler-Nissen, "Enzymic Hydrolysis of Food Proteins," Elsevier Applied Science Publishers Ltd., England, 1986. 
[2] V. Mohr, "Fish Protein Concentrate Production by Enzymic Hydrolysis," In: J. Adler-Nissen, B. O. Eggum, L. Munlic and H. S. Olsen, Eds., Biochemical Aspects of New Protein Food, Proceedings of the 11th FEBS meeting, Federation of European Biochemical Societies, Pergamon Press, Oxford, 1978.

[3] H. G. Kristinsson and B. A. Rasco, "Fish Protein Hydrolysates: Production, Biochemical, and Functional Properties," Critical Reviews in Food Science and Nutrition, Vol. 40, No. 1, 2000, pp. 43-81. doi:10.1080/10408690091189266

[4] A. Himonides, "The Improved Utilisation of Fish Waste, with Particular Reference to the Enzymatic Hydrolysis of Fish Frames for the Production of Fish Protein Hydrolysates," $\mathrm{PhD}$ Thesis, Lincoln University, Lincolnshire, 2001.

[5] V. Stocchi, G. Piccoli, M. Magnani, F. Palma, B. Biagiaralli and L. Cucchiarini, "Reversed-Phase High-Performance Liquid Chromatography Separation of Dimethylaminoazobenzene Sulphonyl- and Dimethy-Laminoazobenzene Thiohydantoin-Amino Acid Derivatives for Amino-Acid Analysis and Microsequensing Studies at the Picomole Level," Analytical Biochemistry, Vol. 178, No. 1, 1989, pp. 107-117. doi:10.1016/0003-2697(89)90364-3

[6] R. Knecht and J. Y. Chang, "Liquid Chromatographic Determination of Amino-Acids after Gas-Phase Hydrolysis and Derivatisation with (Dimethylamino) Azobenzenesulfonyl Chloride," Analytical Chemistry, Vol. 58, No. 12, 1986, pp. 2375-2379. doi:10.1021/ac00125a006

[7] J. Y. Chang, R. Knecht and D. G. Braun, "Amino-Acid Analysis at the Picomole Level," Biochemistry Journal, Vol. 199, No. 3, 1981, pp. 547-555.

[8] S. Bhumiratana, C. G. Hill Jr. and C. H. Amundson, "Enzymatic Solubilization of Fish Protein Concentrate in Membrane Reactors," Journal of Food Science, Vol. 42, No. 4, 1977, pp. 1016-1021.

doi:10.1111/j.1365-2621.1977.tb12657.x

[9] Statutory Instrument, "The Dairy Products (Hygiene) Regulations," Stationery Office Books, UK, No. 1086, 1995.

[10] S. Šližytè, T. Rustad and I. Storrø, "Enzymatic Hydrolysis of Cod (Gadus morhua) by-Products: Optimization of Yield and Properties of Lipid and Protein Fractions," Process Biocemistry, Vol. 40, No. 12, 2005, pp. 36803692. doi:10.1016/j.procbio.2005.04.007

[11] S. Šližyte, E. Daukšas, E. Falch, I. Storrø and T. Rustad, "Yield and Composition of Different Fractions Obtained after Enzymatic Hydrolysis of Cod (Gadus morhua) by-Products," Process Biochemistry, Vol. 40, No. 3-4, 2005, pp. 1415-1424. doi:10.1016/j.procbio.2004.06.033

[12] S. Šližyte, E. Daukšas, E. Falch, I. Storrø and T. Rustad, "Characteristics of Protein Fractions Generated from Hydrolysed Cod (Gadus morhua) by-Products," Process Biochemistry, Vol. 40, No. 6, 2005, pp. 2021-2033. doi:10.1016/i.procbio.2004.07.016

[13] C. Cheftel, M. Ahern, D. I. C. Wang and S. R. Tan- nenbaum, "Enzymatic Solubilization of Fish Protein Concentrate: Batch Studies Applicable to Continuous Enzyme Recycling Processes," Journal of Agricultural and Food Chemistry, Vol. 19. No. 1, 1971, pp. 155-161. doi:10.1021/jf60173a007

[14] S. I. Aspmo, S. J. Horn and V. G. H. Eijsink, "Enzymatic Hydrolysis of Atlantic Cod (Gadus morhua L.) Viscera," Process Biochemistry, Vol. 40, No. 5, 2005, pp. 19571966. doi:10.1016/i.procbio.2004.07.011

[15] G. A. Gbogouri, M. Linder, J. Fanni and M. Parmetier, "Influence of Hydrolysis Degree on the Functional Properties of Salmon by Products Hydrolysates," Journal of Food Science, Vol. 69, No. 8, 2004, pp. 615-622. doi:10.1111/j.1365-2621.2004.tb09909.x

[16] J. Wasswa, J. Tang, X.-H. Gu and X.-Q. Yuan, "Influence of the Extent of Enzymatic Hydrolysis on the Functional Properties of Protein Hydrolysates from Grass Carp (Ctenopharyyngodon idella) Skin," Food Chemistry, Vol. 104, No. 4, 2007, pp. 1698-1704. doi:10.1016/j.foodchem.2007.03.044

[17] Y. J. Jeon, H. G. Byun and S. K. Kim, "Improvement of Functional Properties of Cod Frame Protein Hydrolysates Using Ultrafiltration Membranes," Process Biochemistry, Vol. 35, No. 5, 1999, pp. 471-478. doi:10.1016/S0032-9592(99)00098-9

[18] S. Zhong, C. Ma, Y. C. Lin and Y. Luo, "Antioxidant Properties of Peptide Fractions from Silver Carp ( $\mathrm{Hy}$ pophthalmichthys molitrix) Processing by-Product Protein Hydrolysates Evaluated by Electron Spin Resonance Spectrometry," Food Chemistry, Vol. 126, No. 4, 2011, pp. 1636-1642. doi:10.1016/j.foodchem.2010.12.046

[19] P. Bourseau, L. Vandanjon, P. Jaouen, M. Chaplain- Derouiniot, A. Massé, F. Guérard, A. Chabeaud, M. Fouchereau-Péron, Y. Le Gal, R. Ravallec-Plé, J. P. Bergé, L. Picot, J. M. Piot, I. Batista, G. Thorkelsson, C. Delannoy, G. Jakobsen and I. Johansson, "Fractionation of Fish Protein Hydrolysates by Ultrafiltration and Nanofiltration: Impact on Peptidic Populations," Desalination, Vol. 244, No. 1-3, 2009, pp. 303-320.

doi:10.1016/j.desal.2008.05.026

[20] L. Vandanjon, M. Grignon, E. Courois, P. Bourseau and P. Jaouen, "Fractionating White Fish Fillet Hydrolysates by Ultrafiltration and Nanofiltration," Desalination, Vol. 244, No. 1-3, 2009, pp. 303-320. doi:10.1016/i.desal.2008.05.026

[21] A. Chabeaud, L. Vandanjon, P. Bourseau, P. Jaouen, M. Chaplain-Derouiniot and F. Guerard, "Performances of Ultrafiltration Membranes for Fractionating a Fish Protein Hydrolysate: Application to the Refining of Bioactive Peptidic Fractions," Separtation and Purification Technology, Vol. 66, No. 3, 2009, pp. 463-471. doi:10.1016/j.seppur.2009.02.012

[22] A. Chabeaud, L. Vandanjon, P. Bourseau, P. Jaouen and F. Guérard, "Fractionation by Ultrafiltration of a saithe Protein Hydrolysate (Pollachius virens): Effect of Material and Molecular Weight Cut-off on the Membrane Performances," Journal of Food Engineering, Vol. 91, No. 3, 2009, pp. 408-414. doi:10.1016/j.jfoodeng.2008.09.018 
[23] M. Noguchi, M. Yamashita, I. S. Ara and M. Fujimaki, "On the Bitter Masking Activity of a Glutamic Acid-Rich Oligopeptide Fraction," Journal of Food Science, Vol. 40, No. 2, 1975, pp. 367-370. doi:10.1111/j.1365-2621.1975.tb02203.x

[24] P. Hevia and S. Olcott, "Flavour of Enzyme-Solubilized Fish Protein Concentrate Fractions," Journal of Agricultural and Food Chemistry, Vol. 25, No. 4, 1977, pp. 772-775. doi:10.1021/jf60212a044

[25] G. Lalasides and L. B. Sjorberg, "Two New Methods of Debittering Protein Hydrolyzates and a Fraction of Hydrolyzates with Exceptionally High Contents of Essential Amino-Acids," Journal of Agricultural and Food Chemistry, Vol. 26, No. 3, 1978, pp. 742-749. doi:10.1021/jf60217a056

[26] B. Pedersen, "Removing Bitterness from Protein Hydrolysates," Food Technology, Vol. 45, No. 10, 1994, pp. 96-98.
[27] S. Nilsang, S. Lertsiri, M. Suphantharika and A. Assavanig, "Optimization of Enzymatic Hydrolysis of Fish Soluble Concentrate by Commercial Proteases," Journal of Food Engineering, Vol. 70, No. 4, 2005, pp. 571-578.

[28] M. Friedman, "Nutritional Value of Proteins from Different Food Sources. A Review," Journal of Agricultural and Food Chemistry, Vol. 44, No. 1, 1996, pp. 6-29. doi:10.1021/jf9400167

[29] B. Liaset, K. Julshamn and M. Espe, "Chemical Composition and Theoretical Nutritional Evaluation of the Produced Fractions from Enzymic Hydrolysis of Salmon Frames with Protamex ${ }^{\mathrm{TM}}$," Process Biochemistry, Vol. 38, No. 12, 2003, pp. 1747-1759. doi:10.1016/S0032-9592(02)00251-0

[30] F. Shahidi, X. Q. Han and J. Synowiecki, "Production and Characteristics of Protein Hydrolysates from Capelin (Mallotus villosus)," Food Chemistry, Vol. 53, No. 3, 1995, pp. 285-293. doi:10.1016/0308-8146(95)93934-J 